\title{
Recruitment of coastal fishes and oceanographic variability in central California
}

\author{
J.R. Wilson ${ }^{\text {a, }}$, B.R. Broitman ${ }^{\text {b.c,d, J.E. Caselle }}{ }^{\text {e }}$, D.E. Wendt ${ }^{\mathrm{a}}$ \\ ${ }^{a}$ California Polytechnic State University San Luis Obispo and Center for Coastal Marine Sciences, 1 Grand Ave., San Luis Obispo, CA 93401, USA \\ ${ }^{\mathrm{b}}$ National Center for Ecological Analysis and Synthesis, University of California, Santa Barbara, 735 State St. Suite 300, Santa Barbara, CA 93101, USA \\ ${ }^{c}$ Centro de Estudios Avanzados en Zonas Aridas (CEAZA), Facultad de Ciencias Marinas, Universidad Católica del Norte, Larrondo 1281, Coquimbo, Chile \\ ${ }^{\mathrm{d}}$ Center for Advanced Studies in Ecology and Biodiversity, P. Universidad Católica de Chile, Alameda 340, Santiago, Chile \\ ${ }^{\mathrm{e}}$ Marine Science Institute, University of California, Santa Barbara, CA 93106, USA
}

\begin{abstract}
Recruitment of pelagic larval fishes to the nearshore environment is dependent on a suite of biological and physical processes operating at many spatial and temporal scales. Nearshore circulation processes associated with coastal upwelling are widely upheld as major determinants of year class strength for many rockfishes (Sebastes spp.), but the mechanism by which these processes drive recruitment is largely unknown. We used Standard Monitoring Units for the Recruitment of Fishes (SMURFs) to monitor recruitment of two rockfish complexes (Sebastes spp.) and cabezon (Scorpaenichthys marmoratus) from March to September of 2004 and 2005 at 3 sites along the central California coast. We examined the relationship between recruitment of these fishes and measurements of oceanographic variability associated with upwelling dynamics, including in situ water temperature, AVHRR sea surface temperature, the Bakun upwelling index, and an index of alongshore surface water transport. We found that rockfish comprising the KCGB complex (Sebastes atrovirens, Sebastes caurinus, Sebastes carnatus, Sebastes chrysomelas) recruit during early summer, while fishes of the BYO complex (Sebastes melanops, Sebastes flavidus, Sebastes serranoides), as well as cabezon recruit during late summer. Our results provide limited support for an association between the arrival of juvenile pelagic rockfish and cabezon to the nearshore environment and physical processes related to upwelling and relaxation. Beyond the limitations of our bimonthly sampling scheme, the lack of a clear pattern may be related to the near absence of upwellingrelaxation cycles along this stretch of coast during these two study periods. Moreover, the settlement and recruitment of nearshore fishes may be closely tied to processes occurring earlier in the larval stage.
\end{abstract}

\section{Introduction}

Temporal and spatial variation in the rates of larval recruitment has long been recognized as a strong driver of marine populations and communities (Doherty and Williams, 1988; Doherty, 1991, 2002; Olaffson et al., 1994; Caley et al., 1996; Hixon and Webster, 2002). The ocean circulation processes that facilitate the transport of larvae to nearshore benthic habitats take place across a mosaic of spatial and temporal scales (Shanks, 1995; Caley et al., 1996) and have been implicated as key determinants of year class strength for a number of nearshore benthic species (Parrish et al., 1981; Hollowed et al., 1987). Accordingly, a large body of research has been concerned with establishing the mechanisms, either physical or biological, that generate variation in larval recruitment rates
(Parrish et al., 1981; Gaines and Bertness, 1992; Levin, 1994; Wing et al., 1995b; Schmitt and Holbrook, 1996; Botsford, 2001; Morgan, 2001; Hughes et al., 2002).

The west coast of North America is an eastern boundary ecosystem where spatial and temporal variation in larval recruitment can be influenced by the dynamics of wind-driven coastal upwelling (Parrish et al., 1981; Mooers and Robinson, 1984; Norton, 1987; Graham et al., 1992; Wing et al., 1995b; Connolly et al., 2001). Equatorward wind stress displaces coastal surface waters offshore via Ekman transport, which are replaced by colder, nutrient rich, subsurface waters (Huyer, 1983). Because of their relatively limited locomotory abilities, planktonic larvae may become entrained in the surface Ekman layer and accumulate in offshore coastal fronts (Bjorkstedt et al., 2002). These coastal fronts interact with alongshore current systems, and provide a means for larval dispersal to connect distant populations. Relaxation or reversals in wind stress can lead to downwelling conditions where the warmer offshore surface waters and the coastal fronts are advected back onshore, delivering entrained larval organisms to the 
nearshore benthic habitat (Roughgarden et al., 1988; Farrell et al., 1991). Several studies have shown that variable recruitment of coastal organisms is related to upwelling dynamics in the California region (Parrish et al., 1981; Hollowed et al., 1987; Ebert and Russell, 1988; Roughgarden et al., 1988; Larson et al., 1994; Wing et al., 1995b; Connolly et al., 2001; Broitman et al., 2005; Laidig et al., 2007).

The upwelling-relaxation hypothesis holds that planktonic larvae may be transported cross shelf and alongshore in relation to forcing mechanisms associated with upwelling and relaxation. This is one of the most important mechanistic hypotheses relating the physical transport of pelagic larvae to the nearshore environment (Roughgarden et al., 1988; Cury and Roy, 1989; Farrell et al., 1991). In most ecological studies of invertebrate recruitment, upwelling dynamics have been examined at relatively fine spatial and temporal scales (Gaines and Bertness, 1992; Wing et al., 1995a; Mace and Morgan, 2006a), from which mechanisms of larval transport could be inferred. However, fisheries studies involving upwelling dynamics commonly associate the strength and timing of upwelling throughout a season with an index of year class strength (Larson et al., 1994; Laidig et al., 2007). These fisheries studies have rarely examined specific oceanographic events associated with fish recruitment events.

Many authors have found higher densities of larval rockfishes associated with upwelling fronts in central California (Larson et al., 1994; Sakuma and Ralston, 1995; Bjorkstedt et al., 2002), indicating that upwelling conditions play an integral role in the transport and delivery of larval fishes. For instance, years of above average onshore transport of surface waters in the California current ecosystem resulted in successful widow rockfish (Sebastes entomelas) recruitment classes (Norton, 1987), while strong upwelling during the winter months resulted in low overall juvenile rockfish abundance as examined in seabird diets (Ainley et al., 1993). Other oceanographic indices have also been related to year class strength in certain rockfish species. Water temperature and low sea level anomaly, reflective of an alongshore transport process, were related to weak year classes of black, yellowtail and blue rockfishes in central California (Laidig et al., 2007). Within season variation in recruitment was studied by Ammann (2004), who sampled rockfish recruitment to Standard Monitoring Units for the Recruitment of Fishes (SMURFs) on a near daily basis and found that the black, yellowtail, and olive rockfishes recruited during upwelling events, while the copper, gopher, black and yellow, and kelp rockfishes recruited during relaxation events (Ammann, personal communication). However, it is unclear the extent to which these recruitment patterns are evident throughout the range of these species under variable upwelling regimes.

Understanding the oceanographic conditions conducive to the recruitment of coastal species is central to increasing the predictive capability of fisheries management. The increasing availability of instruments and observational networks that provide oceanographic information can allow us to examine larval transport in relation to environmental variability over unprecedented temporal and spatial scales when coupled with sustained field monitoring programs (Broitman et al., 2005). The objective of the present study is to examine if local patterns of coastal fish recruitment are related to oceanographic variability at local, meso and regional scales. In particular, we attempt to establish if variability during the recruitment season is associated with oceanographic events around the sampling sites, or if this variability is traced to regional-scale oceanography. Using a highly conservative statistical approach, we examine associations between recruitment and temperature and temperature anomalies at the local and meso scales. Then, we contrast these estimates with correlations between recruitment and regionalscale indices of nearshore circulation.

\section{Methods}

\subsection{Study region}

The central coast of California, between Monterey Bay and Point Conception is regarded as the southern end of the California upwelling zone and an area of biogeographic transition (Fig. 1). In this region, predominant northwest winds create upwelling favorable conditions throughout the spring and summer months, and relaxation events occur infrequently (Parrish et al., 1981; Huyer, 1983). We monitored fish recruitment at three sites in San Luis Obispo County. Sites were chosen based on similar habitat, topography, and accessibility. The three sites monitored were (from north to south) San Simeon, Cayucos and Avila Beach, each situated approximately $30 \mathrm{~km}$ from one another and protected to some extent from prevailing wind and current patterns by headlands to the north of each site (Fig. 1, inset).

\subsection{Patterns of larval recruitment}

We used Standard Monitoring Units for the Recruitment of Fishes (SMURFs) (Ammann, 2004) to monitor recruitment of rockfish (Sebastes spp.) and cabezon (Scorpaenichthys marmoratus) from April to September of 2004 and 2005. SMURFs are constructed of plastic mesh fencing rolled into a cylinder approximately $1 \mathrm{~m}$ long and $0.35 \mathrm{~m}$ in diameter, and stuffed with additional plastic fencing as described in Ammann (2004). Settling fishes utilize these artificial structures by entering and exiting through the mesh opening at will. SMURFs are an efficient means to monitor recruitment, because they integrate abundances over each sampling interval, and limit substantial emigration and post-settlement mortality, and when sampled at 2-week intervals they may reflect approximate settlement rates (Ammann, 2004). At each of the sites we placed two groups of SMURFs $1 \mathrm{~km}$ apart from each other. In 2004, each group consisted of four SMURFs, totaling eight at each site, while in 2005 each group consisted of three SMURFs, totaling six at each site. Individual units were separated by $20 \mathrm{~m}$ and all SMURFs were attached to a mooring line $1 \mathrm{~m}$ below the surface in $12-15 \mathrm{~m}$ of water over sandy bottom. Each line was located

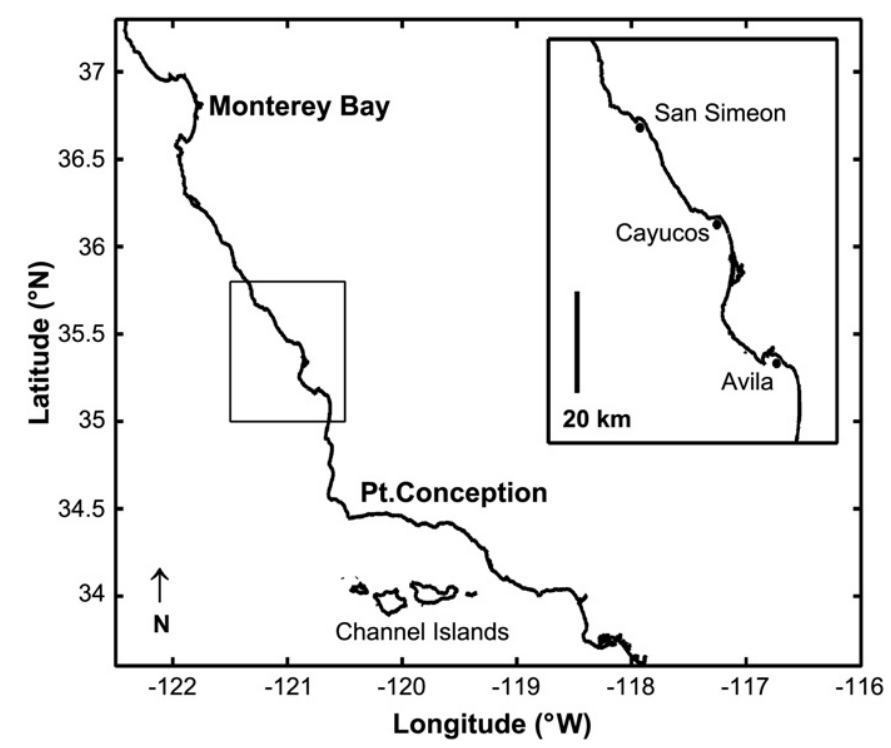

Fig. 1. Map of Central California showing the location of the main topographic features in the area. Large upwelling centers are located south of the Monterey Bay and around Point Conception. The inset shows the Morro Bay area and the location of the three study sites monitored during the spring-summer of 2004 and 2005. 
50-100 m offshore of the most seaward kelp bed/rocky reef. Fishes were collected from SMURFs by a diver using a Benthic Ichthyofaunal Net for Coral/Kelp Environments (BINCKE) (Anderson and Carr, 1998) every 14 days $( \pm 4)$, and identified to the lowest taxonomic group (see below; Moreland and Reilly, 1991). Recruitment was estimated as the number of fish/SMURF per sample per day.

\subsection{Life history}

Rockfishes of the genus Sebastes are an economically and ecologically important group in coastal ecosystems on the west coast of North America. Approximately 55 species of rockfish can be found in waters off the central coast of California (Love et al., 2002). In this study, seven species of rockfish were grouped into two complexes based on morphological and meristic similarities that make identification difficult, as well as similar life history characteristics, habitat associations and timing of recruitment (Anderson, 1983). The KCGB complex includes: kelp (Sebastes atrovirens), copper (Sebastes caurinus), gopher (Sebastes carnatus), and black and yellow (Sebastes chrysomelas) rockfish. The BYO complex includes: black (Sebastes melanops), yellowtail (Sebastes flavidus), and olive (Sebastes serranoides) rockfish.

Reproduction in rockfishes is viviparous; females of the BYO complex undertake parturition during late winter and early spring and larval duration is 2-4 months (Echeverria, 1987; Moser and Boehlert, 1991; Yoklavich et al., 1996). Females of the KCGB complex undertake parturition during late spring and larval duration is 1-2 months (Echeverria, 1987; Moser and Boehlert, 1991; Yoklavich et al., 1996). Competent (i.e. ready to settle) pelagic juveniles of both complexes settle to nearshore benthic habitats, including kelp forests and rocky substrates (Anderson, 1983; Ventresca et al., 1994; Love et al., 2002) during the spring and summer months. Cabezon (Scorpaenichthys marmoratus) is a commercially and economically important nearshore fish of the sculpin family (Cottidae), which lays benthic eggs on hard substrate throughout the year in California with the majority deposited during winter (O'Connell, 1953; Lauth, 1989). Cabezon larvae spend 3-4 months in the pelagic environment, and then settle to nearshore rocky habitat in the spring and summer (O'Connell, 1953).

\subsection{Oceanographic processes}

We examined temporal variation in oceanographic conditions that relate to coastal upwelling circulation. Many of these measurements are dependent on one another, yet they are measured at different spatial scales, and therefore allow us to examine the ideal spatial scale at which to relate to recruitment.

At the local scale, surface and near surface water temperatures are an adequate approximation of upwelling events (Shkedy and Roughgarden, 1997), therefore we recorded in situ ocean temperature every hour throughout the duration of the deployment, using Hobo Water Temp Pro loggers (Onset Computer Corporation) attached to a single mooring line $1 \mathrm{~m}$ below the surface at each site. At the meso scale we used 7-day mean sea surface temperature records from the Advanced Very-High Resolution Radiometer (AVHRR) satellite (Casey and Cornillon, 1999) with a nominal resolution of $4 \mathrm{~km}^{2}$. AVHRR data were averaged over a $40 \times 40 \mathrm{~km}$ region centered on the coastal portion of each study site to minimize the number of dates with missing data due to cloud cover (Broitman et al., 2005). AVHRR areas overlapped each adjacent region by approximately $10 \mathrm{~km}$. At the regional scale, we used the $1 \times 1^{\circ}$ daily coastal upwelling index (Bakun, 1973) and the alongshore transport index from the Pacific Fisheries Environmental Laboratories (PFEL, http://www.pfeg.noaa.gov) closest to the study region $\left(36^{\circ} \mathrm{N} 122^{\circ} \mathrm{W}\right)$. Positive values for the upwelling index indicate upwelling conditions (offshore surface flow) while negative values indicate relaxation of upwelling (onshore surface flow). For alongshore transport indices, negative values indicate equatorward flow and positive values indicate poleward flow.

\subsection{Statistical analyses}

We examined the association between oceanographic measurements and fish recruitment rates by conducting temporal cross-correlations. Since AVHRR data were available as 7-day means, we filtered the logger temperature, upwelling, and alongshore transport data using a 7-day moving average. We carried out lagged correlations between recruitment rates and filtered physical data with a 1-day (lag-1) and a 7-day temporal lag (lag-7). This translated to examining a mean of the physical data for the week immediately preceding collections (lag-1), as well as the week prior to this (lag-7). To examine the role of event-scale physical processes in delivering larvae, we used linear regression to remove the seasonal trend observed during each sampling season for logger temperature data and used the resulting time series of daily local ocean temperature anomalies for correlations. Similarly, we removed serial correlation of the AVHRR readings by using a 10-year long climatology to calculate weekly anomalies (see Section 3). It was not possible to transform the fish recruitment data to meet normality assumptions of parametric statistics, so we used a non-parametric estimator of association, Kendall's tau $\left(r_{\tau}\right)$ to calculate correlations between physical variables and larval recruitment rates. Kendall's tau $\left(r_{\tau}\right)$ is an estimator of concordance, and also reduces the effects of temporal autocorrelation apparent in the seasonal distributions of non-detrended physical measurements as well as recruitment time series. To ensure a highly conservative estimation of the significance of the association between time series, we used 10,000 Monte Carlo iterations to bootstrap the calculation of $r_{\tau}$. Then, we used the resulting distributions of $r_{\tau}$ to estimate the $90 \%$ and $95 \%$ confidence intervals to test whether the correlations between oceanographic variables and recruitment rates were significantly different from zero using a two-tailed hypothesis (Manly, 1997; Martinez and Martinez, 2002). All analyses were carried out using Matlab 7 R14.0.2 (The Mathworks, Inc., Natick, MA).

\section{Results}

\subsection{Physical processes}

Local temperature variability as recorded by in situ temperature loggers and AVHRR satellite data showed a clear seasonal trend increasing linearly from the onset of spring towards the end of the summer (Fig. 2A-C). In general, northern sites (San Simeon and Cayucos, Fig. 2A and B, respectively) experienced colder water conditions than the southern site (Avila Beach, Fig. 2C) with a persistent $\sim 1.5^{\circ} \mathrm{C}$ difference between San Simeon and Avila Beach. The seasonal trend was marked by large events of cooling and warming that took place synchronously across all sites.

During the two study periods, cloudiness associated with persistent upwelling conditions reduced the number of temperature retrievals in the AVHRR record from the $1600 \mathrm{~km}^{2}$ region at San Simeon by $16 \%$, at Cayucos by $18 \%$ and at Avila Beach by $28 \%$. However, correlation analyses of AVHRR with in situ temperature records showed that local temperature loggers correlated reasonably well with the meso scale (AVHRR) thermal variability at no lag (Supplementary Table 2, online supporting material). Time series of the upwelling index showed that the region was subject to persistent seasonal upwelling conditions with maximal values during the boreal spring (May-June, Fig. 2D). In agreement with the persistent upwelling conditions, equatorward surface water flow was observed throughout the settling season. Similar to the correlations 

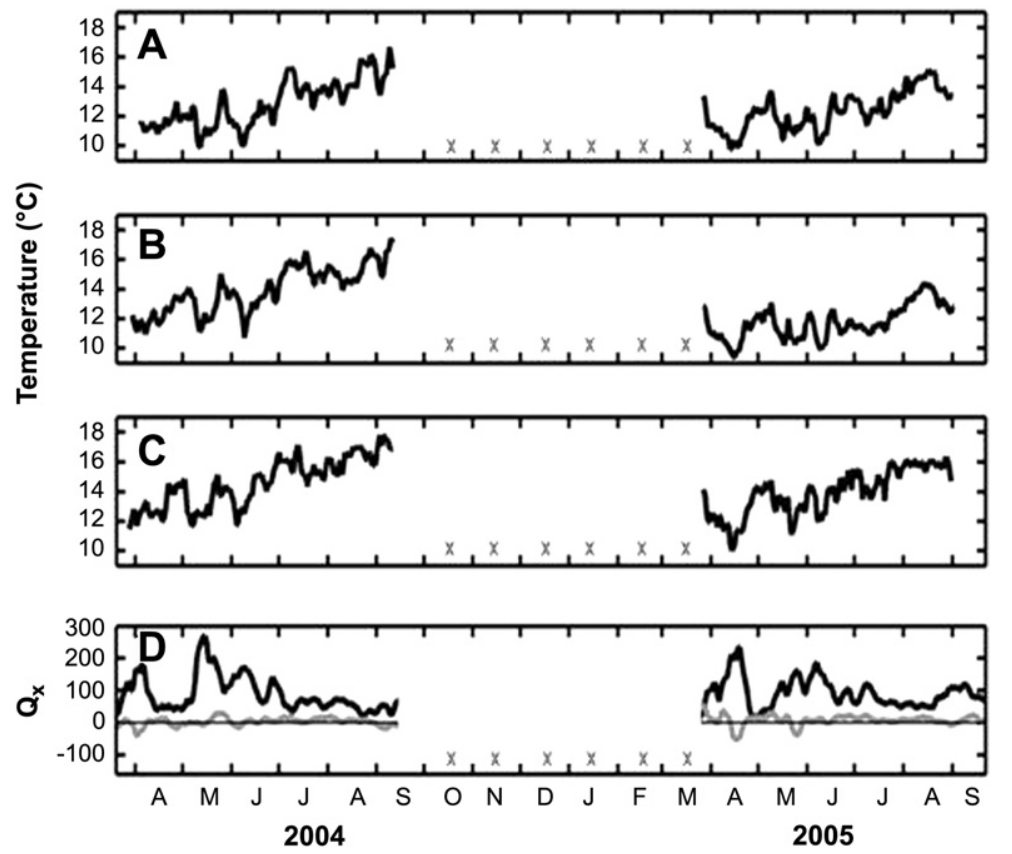

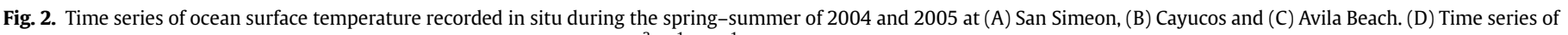
Ekman transport (black line) and alongshore transport (grey line) $\left(Q_{x}, \mathrm{~m}^{3} \mathrm{~s}^{-1} \mathrm{~km}^{-1}\right)$ at $36 \times 122^{\circ}$. $\mathrm{X}$ indicates no sampling.

between AVHRR and in situ temperature, we evaluated the relationship between all oceanographic variables at both lags using correlation analysis. Upwelling and sea surface temperature readings (local and AVHRR) showed significant negative correlations at all sites, while alongshore transport had few significant correlations with either water temperature or upwelling. However, the signs of nearly all the values conformed to the predictions that upwelling and sea surface temperature are negatively correlated, and alongshore transport and sea surface temperature are positively correlated (Supplementary Table 2, online supporting material).

\subsection{Recruitment patterns}

Recruitment of juvenile rockfishes was highly variable in space and time. In 2004, recruitment rates of the BYO complex to SMURFs were lowest at the northernmost site, San Simeon (Fig. 3A), and increased southward (Fig. 3B,C). Recruitment in 2005, however, was limited to three individuals, suggesting a possible year class failure in our study region. For KCGB, spatial patterns of recruitment were similar to the BYO group; lower in the north and higher in the south (Fig. 4C). Unlike BYO, recruitment of KCGB was greater in 2005 than 2004 (Fig. 4A,B,C). Patterns of cabezon recruitment for both years were highest at the coldest, northernmost site (San Simeon), followed by Avila Beach and then Cayucos (Fig. 5).

Intra-annual variation in recruitment rates followed a clear taxa-specific seasonal cycle that was observed across all sites. Recruitment of the BYO complex began in early April and ended by the beginning of July in 2004. Peak recruitment occurred during May and June at all three sites. The southernmost site, Avila Beach (Fig. 3C), peaked 2 weeks earlier than the other sites. In 2005, the few BYO individuals that recruited arrived in late April coinciding with the beginning of the 2004 recruitment season for this complex.

Recruitment of the KCGB complex began with a small pulse during May of 2004 at Cayucos and San Simeon. Recruitment rates decreased in June but peaked again in late July and early August at
Avila coinciding with smaller peaks at Cayucos and San Simeon. The 2005 recruitment season of the KCGB complex started much later and recruitment rates started to increase in early June at Avila and San Simeon and peaked in July and August at all three sites. Recruitment rates appeared relatively high at all sites when collecting stopped in early September, in contrast to the 2004 season in which recruitment was minimal by early September. Cabezon had already begun recruiting at Avila and San Simeon when collections commenced in mid-April of 2004 and 2005. During both years recruitment rates were high early in the season at all three sites, persisted until mid-August and appeared to have stopped by the time collecting ended in mid-September.

\subsection{Relationships with oceanographic data}

Local water temperature was generally well correlated with recruitment of nearshore fishes (Table $1 \mathrm{~A}$ ). Nearly all sites showed significant relationships between recruitment of KCGB and warm water, as well as recruitment of cabezon and cold water. Fewer significant relationships for the BYO complex and local water temperature were apparent. Our estimate of meso scale oceanographic variability, AVHRR SST, was not well correlated to coastal fish recruitment, with considerably fewer significant correlations observed for any of the taxa (Table 1C).

To determine if recruitment variability was associated with thermal events, we removed the seasonal trend in the data and examined the association between recruitment and temperature anomalies for both the logger data (Table 1B), and AVHRR data (Table 1D). We found few significant associations with these data, and on occasion the signs of our correlation estimates switched relative to data in which the seasonal trend was retained.

When we evaluated coastal fish recruitment in relation to our proxies of regional oceanographic variability, the Bakun upwelling index and an alongshore transport index, we found few significant correlations. Although these results indicate limited support for relationships between recruitment and regional surface water transport indices, it is interesting to note that the sign of the correlation values generally conformed to our hypotheses. Negative 


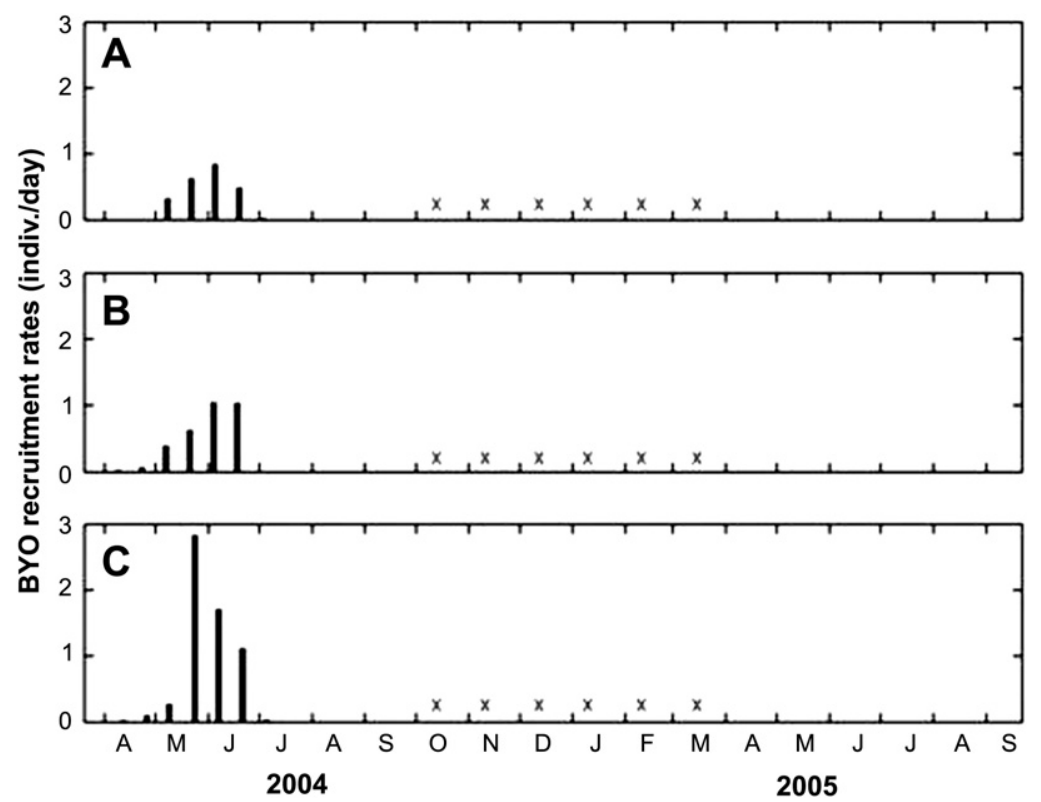

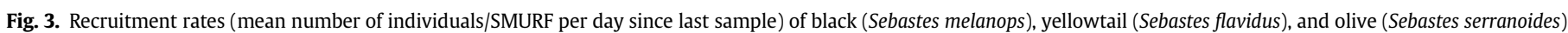
rockfish (BYO complex) at (A) San Simeon, (B) Cayucos and (C) Avila Beach. X indicates no sampling.

correlation values with upwelling suggest recruitment during relaxation events while positive values indicate recruitment during regional-scale upwelling events (Table 1E). For alongshore transport, a negative relationship indicates recruitment during poleward flow, while a positive relationship indicates recruitment during equatorward flow (Table $1 \mathrm{~F}$ ).

\section{Discussion}

Here, we compared recruitment variability of commercially important fish species with oceanographic variability across a hierarchy of spatial and temporal scales in an attempt to build a predictive framework for the recruitment of coastal fish species. We examined the association of fish recruitment to four different oceanographic measurements that either directly (upwelling index, alongshore transport) or indirectly (temperature logger, AVHRR SST) relate to coastal upwelling circulation. We found that the BYO complex and cabezon recruit in spring during periods of cold water, suggesting an association with upwelling and equatorward surface water flow. In contrast, the KCGB complex recruits later in the summer in relation to warm water, relaxation of upwelling and poleward flow. However, recruitment was not observed to be significantly related to specific thermal events either directly or indirectly associated with upwelling and relaxation. These results suggest that the nearshore transport of competent pelagic rockfish and cabezon is tied to a seasonal cycle of spawning and pelagic larval duration, rather than specific oceanographic events driving the onshore migration of these individuals along this stretch of coast.

In a recent study north of our region in Monterey Bay, Ammann (personal communication) found that event-scale

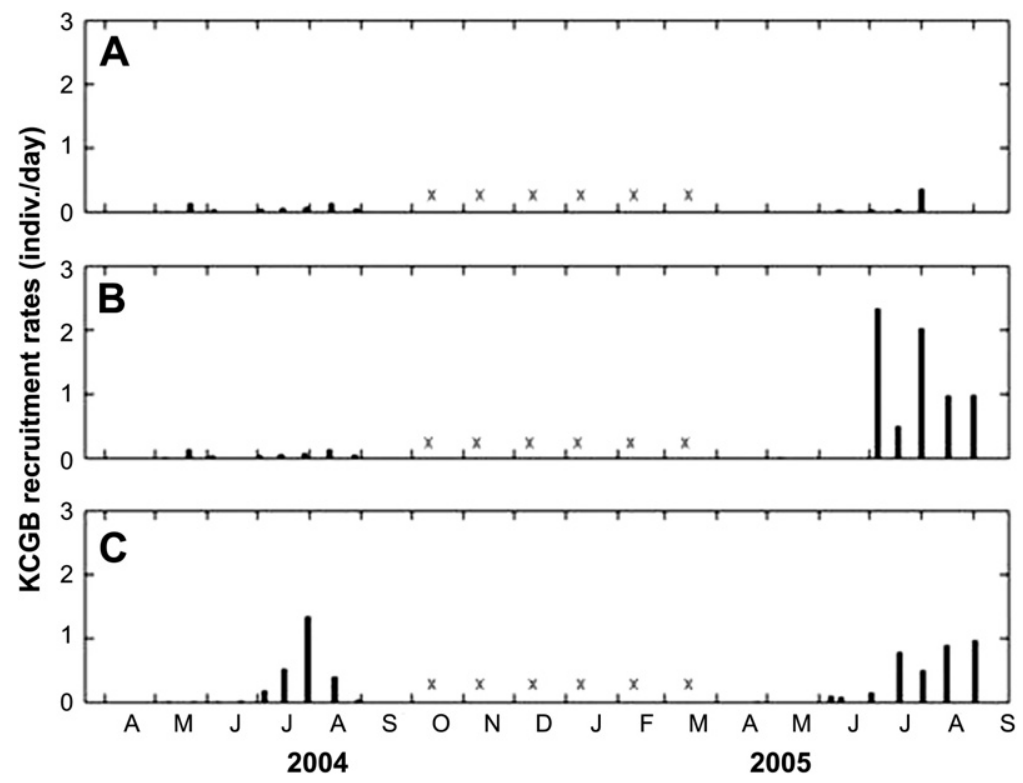

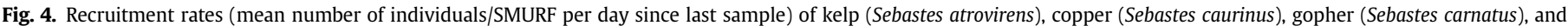
black and yellow (Sebastes chrysomelas) rockfish (KCGB complex), at (A) San Simeon, (B) Cayucos and C) Avila Beach. X indicates no sampling. 


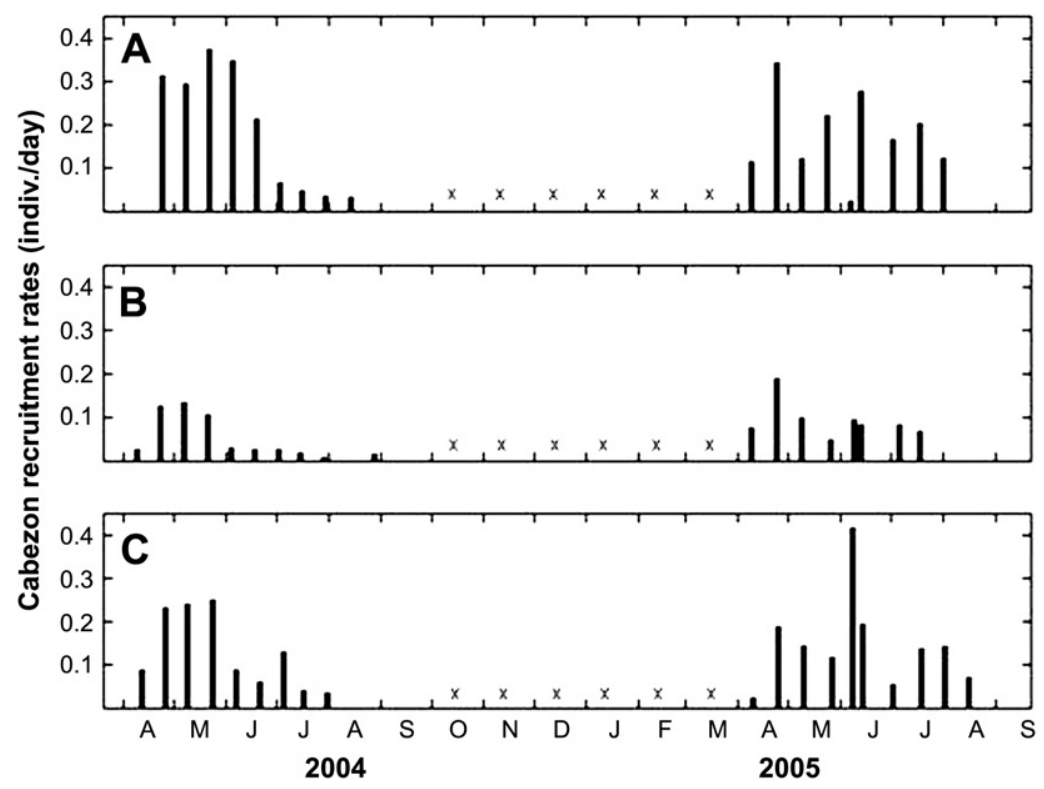

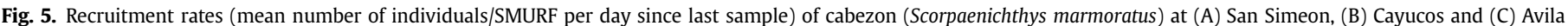
Beach. X indicates no sampling.

upwelling-relaxation cycles were related to the recruitment of the BYO and KCGB complexes. Although we found no consistent significant correlations between event-scale upwelling and relaxation events in our region, there are a number of hypotheses as to why this may be true. First, it is possible that recruitment of rockfish and cabezon in Monterey Bay is more closely linked to physical processes than in our study region, which is at the southern end of the central California upwelling zone, and an area of oceanographic transition.

Second, it is possible that the paucity of significant correlations may arise from a scale mismatch between the frequency of the recruitment sampling and the spatial and temporal scales of the relevant physical process. The 2 -week interval between sampling dates may encompass the effects of multiple upwelling/relaxation events (Send et al., 1987) confounding event-scale oceanographic relationships with the recruitment of larvae (Pineda, 2000). In addition, three of our measurements (AVHRR, upwelling and alongshore transport) are indices of oceanographic variability that encompass increasingly larger spatial scales (see Section 2.4). The processes driving local recruitment may operate at much finer spatial scales (Carr and Syms, 2006) and therefore our study may not have detected a clear association between local recruitment and regional oceanographic processes. On the other hand, the processes driving recruitment may occur at extremely large scales, thus decoupling local recruitment from local scale physical factors.

Lastly, the relative lack of significant correlations between recruitment and event scale oceanographic processes may also be explained by the adequate swimming ability of these fishes and their behavioral adaptations to exploit preferred food sources and avoid predation (Parrish et al., 1981; Lenarz et al., 1991; Sogard and Olla, 1996). Late stage juvenile pelagic rockfish are strong swimmers and can actively migrate nearshore (Moser and Boehlert, 1991), thus they may follow food sources to the nearshore environment or respond to a physiological cue to settle during a certain developmental window regardless of the nearshore transport processes occurring. This hypothesis would support the idea that at fine temporal scales, recruitment is unrelated to oceanographic forcing. It also implies that within season variability in upwelling and relaxation may not be as important in determining the strength of a recruitment year class as the seasonal magnitude of upwelling (Ralston and Howard, 1995; Laidig et al., 2007).
We documented a year class failure in the BYO complex during 2005 across all three study sites. Similarly, this complex was absent from other studies along the California coast during 2005 (J. Caselle, unpublished data). It is unclear whether the recruitment failure was a function of physical processes acting in opposition to the survival of pelagic stages or the lack of a substantial larval pool due to limited production. We suggest that the similarities between study sites in California indicate that year class strength and the failure of the BYO complex in 2005 may be a function of limited production of larvae, early larval mortality or some interaction between the two. Larval tows conducted off the coast of central California by NOAA Fisheries recorded very few individuals of the BYO complex in early 2005 (S. Ralston, personal communication) suggesting that events during the winter months and/or early spring were most responsible for the failure of this complex. Interestingly the spring of 2005 was an anomalous year for oceanographic transport processes in the northeast Pacific Ocean (Barth et al., 2007). Upwelling was delayed 1-3 months along regions of North America with increased surface water temperatures, low chlorophyll $a$ levels and a redistribution of zooplankton communities (Schwing et al., 2006). This delayed upwelling likely had profound implications on survival and recruitment of rockfish and cabezon in Oregon and northern California (Barth et al., 2007). Visual examination of the timing of upwelling in 2004 and 2005 in relation to the long-term harmonic did not indicate delayed upwelling at our study sites in south central California.

To determine whether abnormal upwelling conditions during the pelagic larval phase of the BYO complex contributed to the year class failure in 2005, we evaluated the mean upwelling indices in the winters of 2004 and 2005 for the 120 days prior to settlement and compared them to the long-term mean from the period calculated using harmonic regression. The winter of 2005 had significantly higher upwelling compared to the harmonic (ANOVA, $p<0.01$, Tukey's post hoc $p<0.01$ ), while the winter of 2004 did not (ANOVA, $p<0.01$, Tukey's post hoc $p>0.05$ ). The winter of 2005 also had significantly stronger upwelling than the winter of 2004 (ANOVA, $p<0.01$, Tukey's post hoc $p>0.05$ ). Although the significantly higher upwelling does not correspond to the delayed upwelling season reported in the northeast Pacific Coast of the US during 2005, it does suggest that strong upwelling during winter 
Table 1

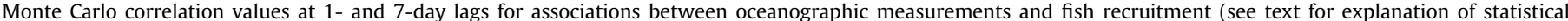

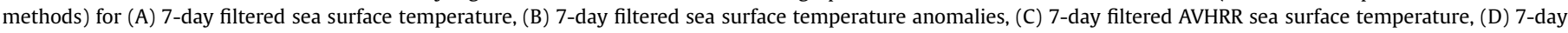

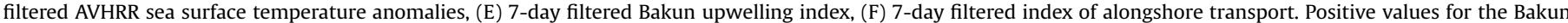

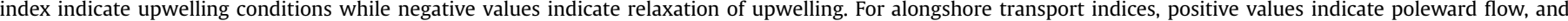
negative values indicate equatorward flow. * indicates significant difference from zero using $90 \% \mathrm{CI}$. ** indicates significant difference from zero using $95 \% \mathrm{CI}$.

\begin{tabular}{|c|c|c|c|c|c|c|}
\hline \multirow[t]{2}{*}{ Lag (days) } & \multicolumn{2}{|l|}{ KCGB } & \multicolumn{2}{|l|}{ BYO } & \multicolumn{2}{|l|}{ Cabezon } \\
\hline & 1 & 7 & 1 & 7 & 1 & 7 \\
\hline \multicolumn{7}{|c|}{$\begin{array}{l}\text { A. 7-day filtered sea } \\
\text { surface temperature }\end{array}$} \\
\hline San Simeon & $0.41^{* *}$ & $0.44^{* *}$ & -0.25 & -0.16 & $-0.56^{* *}$ & $-0.53^{* *}$ \\
\hline Cayucos & $0.35^{* *}$ & 0.15 & 0.05 & 0.09 & $-0.37^{* *}$ & $-0.39^{* *}$ \\
\hline Avila Beach & $0.44^{* *}$ & $0.42^{* *}$ & -0.19 & $-0.35^{* *}$ & $-0.38^{* *}$ & -0.43 \\
\hline \multicolumn{7}{|c|}{$\begin{array}{l}\text { B. 7-day filtered sea } \\
\text { surface temperature } \\
\text { anomalies }\end{array}$} \\
\hline San Simeon & -0.02 & 0.00 & -0.28 & -0.14 & $-0.32^{*}$ & -0.15 \\
\hline Cayucos & 0.08 & 0.05 & 0.05 & -0.09 & -0.07 & -0.07 \\
\hline Avila Beach & 0.02 & -0.09 & 0.04 & -0.23 & 0.01 & -0.17 \\
\hline \multicolumn{7}{|c|}{$\begin{array}{l}\text { C. 7-day filtered AVHRR } \\
\text { sea surface temperature }\end{array}$} \\
\hline San Simeon & 0.12 & -0.21 & -0.46 & $-0.42^{* *}$ & -0.69 & -0.31 \\
\hline Cayucos & $0.23^{*}$ & 0.02 & $-0.40^{* *}$ & -0.25 & -0.50 & -0.03 \\
\hline Avila Beach & 0.18 & 0.02 & -0.25 & -0.31 & -0.02 & -0.06 \\
\hline \multicolumn{7}{|c|}{$\begin{array}{l}\text { D. 7-day filtered AVHRR } \\
\text { sea surface temperature } \\
\text { anomalies }\end{array}$} \\
\hline San Simeon & -0.33 & -0.25 & -0.43 & -0.18 & -0.37 & -0.06 \\
\hline Cayucos & -0.29 & 0.12 & 0.07 & 0.00 & 0.09 & $0.39^{* *}$ \\
\hline Avila Beach & 0.00 & -0.14 & -0.30 & -0.21 & -0.13 & -0.03 \\
\hline \multicolumn{7}{|c|}{$\begin{array}{l}\text { E. 7-day filtered Bakun } \\
\text { upwelling index }\end{array}$} \\
\hline San Simeon & -0.17 & -0.05 & 0.34 & 0.34 & $0.36^{*}$ & $0.44^{* *}$ \\
\hline Cayucos & -0.24 & -0.17 & 0.18 & 0.14 & $0.30^{*}$ & 0.23 \\
\hline Avila Beach & -0.20 & -0.11 & 0.16 & $0.34^{* *}$ & 0.22 & 0.25 \\
\hline \multicolumn{7}{|c|}{$\begin{array}{l}\text { F. 7-day filtered index } \\
\text { of alongshore transport }\end{array}$} \\
\hline San Simeon & 0.25 & -0.04 & -0.13 & -0.16 & -0.13 & -0.08 \\
\hline Cayucos & 0.26 & 0.17 & -0.23 & -0.13 & 0.19 & -0.03 \\
\hline Avila Beach & 0.14 & 0.14 & -0.07 & -0.22 & 0.05 & 0.06 \\
\hline
\end{tabular}

may reduce the chance of a successful recruitment year for BYO (Ainley et al., 1993).

This hypothesis also corroborates work conducted in Central California by Larson et al. (1994) who suggested that year class strength is determined early in the larval life history of rockfish species during the winter and early spring, the time at which the BYO complex would have been undergoing parturition and existing in the pelagic stage. Given the lack of significant correlations between recruitment and event-scale thermal variability in our study, we support the hypothesis that successful recruitment years for rockfish and cabezon are largely determined earlier in the life history and are not directly related to oceanographic transport processes at the pelagic juvenile stage.

The connections between recruitment variability and oceanographic forcing bear major implications for the spatial structure of fish populations, as larval supply can drive the population dynamics of nearshore fishes (Parrish et al., 1981; Doherty, 1991; Caley et al., 1996). In order to conserve and manage coastal ecosystems, there is an emerging need to identify and quantify larval transport processes operating at multiple spatial and temporal scales. Often these scales operate over long periods of time, and the limited duration of this study precludes stronger interpretation of the effects of environmental variability on nearshore fish population dynamics. We have shown that field-based studies can be coupled with routine physical data and publicly available oceanographic information to provide information regarding regional variation in patterns of recruitment to the nearshore environment.
Understanding these linkages is critical for the proper management of fish stocks and will allow better predictive capabilities in determining future sustainable harvest quotas. Moreover, the mechanistic identification of oceanographic settings that can lead to different scenarios of larval input will aid in contemporary ecosystem-based management initiatives such as the appropriate size and spacing of marine reserves (Botsford, 2001; Mace and Morgan, 2006b).

\section{Acknowledgments}

We thank Erin Nakada, Collin Johnson, Nicole Molinari and numerous others for field and lab help. This research was supported by a grant to D.E.W. by the Resources Legacy Fund Foundation and to J.R.W. by the Cal Poly Student Fee Committee. B.R.B. acknowledges support from NCEAS, a center funded by NSF (Grant \#DEB-0553768), the University of California, Santa Barbara, and the State of California. Earlier drafts of this manuscript were improved by helpful comments from Bob Warner and the labroids, Arnold Ammann, Mary Nishimoto, and two anonymous reviewers. The Monterey Bay National Marine Sanctuary (MBNMS-2005-0013) provided permits to sample at San Simeon, CA.

\section{Appendix A. Supplemental material}

Supplementary information for this manuscript can be downloaded at doi: 10.1016/j.ecss.2008.05.001. 


\section{References}

Ainley, D.G., Sydeman, W.J., Parrish, R.H., Lenarz, W.H., 1993. Oceanic factors influencing distribution of young rockfish (Sebastes spp.) in central California: a predator's perspective. California Cooperative Oceanic Fisheries Investigations Reports 34, 133-139.

Ammann, A.J., 2004. SMURFs: standard monitoring units for the recruitment of temperate reef fishes. Journal of Experimental Marine Biology and Ecology 299, 135-154.

Anderson, T.W., 1983. Identification and development of nearshore juvenile rockfishes (genus Sebastes) in central California kelp forests. Master's thesis, California State University, Fresno, CA, 216 pp.

Anderson, T.W., Carr, M.H., 1998. BINCKE: a highly efficient net for collecting reef fishes. Environmental Biology of Fishes 51, 111-115.

Bakun, A., 1973. Coastal upwelling indices, west coast of North America 1946-1971. US Department of Commerce, NOAA Technical Report, NMFS, SSRF-671, 103 pp.

Barth, J.A., Menge, B.A., Lubchenco, J., Chan, F., Bane, J.M., Kirincich, A.R. McManus, M.A., Nielsen, K.J., Pierce, S.D., Washburn, L., 2007. Delayed upwelling alters nearshore coastal ocean ecosystems in the northern California current. Proceedings of the National Academy of Sciences USA 104, 3719-3724.

Bjorkstedt, E.P., Rosenfeld, L.K., Grantham, B.A., Shkedy, Y., Roughgarden, J., 2002. Distributions of larval rockfishes (Sebastes spp.) across nearshore fronts in a coastal upwelling region. Marine Ecology Progress Series 242, 215-228.

Botsford, L.W., 2001. Physical influences on recruitment to California Current invertebrate populations on multiple scales. ICES Journal of Marine Science 58, 1081-1091.

Broitman, B.R., Blanchette, C.A., Gaines, S.D., 2005. Recruitment of intertidal invertebrate and oceanographic variability at Santa Cruz Island, California. Limnology and Oceanography 50, 1473-1479.

Caley, M.J., Carr, M.H., Hixon, M.A., Hughes, T.P., Jones, G.P., Menge, B.A., 1996. Recruitment and the local dynamics of open marine populations. Annual Review of Ecology and Systematics 27, 477-500.

Carr, M.H., Syms, C., 2006. Recruitment. In: Pondella, D.J., Allen, L.G., Horn, M.H. (Eds.), The Ecology of Marine Fishes: California and Adjacent Waters. University of California Press, Berkeley and Los Angeles, pp. 411-427. CA.

Casey, K.S., Cornillon, P., 1999. A comparison of satellite and in situ-based sea surface temperature climatologies. Journal of Climate 12, 1848-1863.

Connolly, S.R., Menge, B.A., Roughgarden, J., 2001. A latitudinal gradient in recruitment of intertidal invertebrates in the northeast Pacific Ocean. Ecology $82,1799-1813$.

Cury, P., Roy, C., 1989. Optimal environmental window and pelagic fish recruitment success in upwelling areas. Canadian Journal of Fisheries and Aquatic Sciences 46, 670-680.

Doherty, P.J., 1991. Spatial and temporal patterns in recruitment. In: Sale, P.F.(Ed.), The Ecology of Fishes on Coral Reefs. Academic Press, San Diego, CA, pp. 261-293.

Doherty, P.J., 2002. Variable replenishment and the dynamics of reef fish populations. In: Sale, P.F. (Ed.), Coral Reef Fishes: Dynamics and Diversity in a Complex Ecosystem. Academic Press, San Diego, CA, pp. 327-355.

Doherty, P.J., Williams, D.M., 1988. The replenishment of coral reef fish populations. Oceanography and Marine Biology Annual Review 26, 487-551.

Ebert, T.A., Russell, M.P., 1988. Latitudinal variation in size structure of the West coast purple sea urchin: a correlation with headlands. Limnology and Oceanography 33, 286-294.

Echeverria, T.W., 1987. Thirty-four species of California rockfishes maturity and seasonality of reproduction. Fishery Bulletin 85, 229-250.

Farrell, T.M., Bracher, D., Roughgarden, J., 1991. Cross-shelf transport causes recruitment to intertidal populations in central California. USA. Limnology and Oceanography 36, 279-288.

Gaines, S.D., Bertness, M.D., 1992. Dispersal of juveniles and variable recruitment in sessile marine species. Nature 360, 579-580.

Graham, W.M., Field, J.G., Potts, D.C., 1992. Persistent "upwelling shadows" and their influence on zooplankton distributions. Marine Biology 114, 561-570.

Hixon, M.A., Webster, M.S., 2002. Density dependence in marine fishes: coral-reef populations as model systems. In: Sale, P.F.(Ed.), Coral Reef Fishes: Dynamics and Diversity in a Complex Ecosystem. Academic Press, San Diego, CA, pp. 303-325.

Hollowed, A.B., Bailey, K.M., Wooster, W.S., 1987. Patterns in recruitment of marine fishes in the northeast pacific ocean. Biological Oceanography 5, 99-132.

Hughes, T.P., Baird, A.H., Dinsdale, E.A., Harriott, V.J., Moltschaniwskyj, N.A., Pratchett, M.S., Tanner, J.E., Willis, B.L., 2002. Detecting regional variation using meta-analysis and large-scale sampling: latitudinal patterns in recruitment. Ecology 83, 436-451.

Huyer, A., 1983. Coastal upwelling in the California current system. Progress in Oceanography $12,259-284$

Laidig, T.E., Chess, J.R., Howard, D.F., 2007. Relationship between abundance of juvenile rockfishes (Sebastes spp.) and environmental variables documented off northern California and potential mechanisms for the covariation. Fishery Bulletin 105, 39-48

Larson, R.J., Lenarz, W.H., Ralston, S., 1994. The distribution of pelagic juvenile rockfish of the genus Sebastes in the upwelling region off central California. California Cooperative Oceanic Fisheries Investigations Reports 35, 175-221.

Lauth, R.R., 1989. Seasonal spawning cycle, spawning frequency, and batch fecundity of the Cabezon (Scorpaenichthys marmoratus) in Puget Sound, Washington, USA. Fishery Bulletin 87, 145-154.
Lenarz, W.H., Larson, R.J., Ralston, S., 1991. Depth distributions of late larvae and pelagic juveniles of some fishes of the California Current. California Cooperative Oceanic Fisheries Investigations Reports 32, 41-46.

Levin, P.S., 1994. Fine-scale temporal variation in recruitment of a temperate demersal fish: the importance of settlement versus post-settlement loss. Oecologia 97, 124-133.

Love, M.S., Yoklavich, M., Thorsteinson, L., 2002. The Rockfishes of the Northeast Pacific. University of California Press, Berkeley and Los Angeles, CA, 404 pp.

Mace, A.J., Morgan, S.G., 2006a. Biological and physical coupling in the lee of a small headland: contrasting transport mechanisms for crab larvae in an upwelling region. Marine Ecology Progress Series 324, 185-196.

Mace, A.J., Morgan, S.G., 2006b. Larval accumulation in the lee of a small headland: implications for the design of marine reserves. Marine Ecology Progress Series 318, 19-29.

Manly, B.F.J., 1997. Randomization, Bootstrap and Monte Carlo Methods in Biology. CRC Press, Boca Raton, FL, 428 pp.

Martinez, W.L., Martinez, A.R., 2002. Computational Statistics Handbook with Matlab. CRC Press, Boca Raton, FL, 591 pp.

Mooers, C.N.K., Robinson, A.R., 1984. Turbulent jets and eddies in the California Current Pacific Ocean and inferred cross shore transports. Science 223, 51-53.

Moreland, S.L., Reilly, C.A., 1991. Key to the juvenile rockfishes of central California In: Laidig, T.E., Adams, P.B. (Eds.), Methods Used to Identify Pelagic Juvenile RockfishGenus Sebastes. Occurring Along the Coast of Central California. US Department of Commerce, NOAA Technical Memorandum, NMFS, pp. 59-180.

Morgan, S.G., 2001. The larval ecology of marine communities. In: Bertness, M.D. Gaines, S.D. (Eds.), Marine Community Ecology. Sinauer Associates, Sunderland, MA, pp. 159-181.

Moser, H.G., Boehlert, G.W., 1991. Ecology of pelagic larvae and juveniles of the genus Sebastes. Environmental Biology of Fishes 30, 203-224.

Norton, J., 1987. Ocean climate influences on groundfish recruitment in the California Current. In: Proceedings of the International Rockfish Symposium, Anchorage, Alaska (AK Sea Grant Rep 87-2). University of Alaska, Anchorage, pp. 73-99.

O'Connell, C.P., 1953. The life history of the cabezon, Scorpaenichthys marmoratus (Ayres). California Department of Fish and Game. Fishery Bulletin 93, 1-76.

Olaffson, E.B., Peterson, C.H., Ambrose, W.G., 1994. Does recruitment limitation structure populations and communities of macroinvertebrates in marine soft sediments: the relative significance of pre- and post-settlement processes. Annual Review of Oceanography and Marine Biology 32, 65-109.

Parrish, R.H., Nelson, C.S., Bakun, A., 1981. Transport mechanisms and reproductive success of fishes in the California current. Biological Oceanography 1, 175-203.

Pineda, J., 2000. Linking larval settlement to larval transport: assumptions, potentials, and pitfalls. In: Färber-Lorda, J. (Ed.), Oceanography of the Eastern Pacific, vol. 1. CICESE, Ensenada, Baja California, Mexico, pp. 84-105.

Ralston, S., Howard, D.F., 1995. On the development of year-class strength and cohort variability in two northern California rockfishes. US National Marine Fisheries Service Fishery Bulletin 93, 710-720.

Roughgarden, J., Gaines, S.D., Possingham, H., 1988. Recruitment dynamics in complex life cycles. Science 241, 1460-1466.

Sakuma, K.M., Ralston, S., 1995. Distributional patterns of late larval groundfish off central California in relation to hydrographic features during 1992 and 1993. California Cooperative Oceanic Fisheries Investigations Reports 36, 179-192.

Schmitt, R.J., Holbrook, S.J., 1996. Local-scale patterns of larval settlement in a planktivorous damselfish: do they predict recruitment? Marine and Freshwater Research 47, 449-463.

Schwing, F.B., Bond, N.A., Bograd, S.J., Mitchell, T., Alexander, M.A., Mantua, N., 2006. Delayed coastal upwelling along the US West Coast in 2005: a historical perspective. Geophysical Research Letters 33, 1-5.

Send, U., Beardsley, R.C., Winant, C.D., 1987. Relaxation from upwelling in the Coastal Ocean Dynamics Experiment. Journal of Geophysical Research 92, $1683-1698$

Shanks, A.L., 1995. Mechanisms of cross-shelf dispersal of marine invertebrates. In McEdward, L.R. (Ed.), Ecology of Marine Invertebrate Larvae. Marine Science Series. CRC Press, Boca Raton, FL, pp. 323-367.

Shkedy, Y., Roughgarden, J., 1997. Barnacle recruitment and population dynamics predicted from coastal upwelling. Oikos 80, 487-498.

Sogard, S.M., Olla, B.L., 1996. Food deprivation affects vertical distribution and activity of a marine fish in a thermal gradient: potential energy-conserving mechanisms. Marine Ecology Progress Series 133, 43-55.

Ventresca, D.A., Houk, J.L., Paddack, M.J., Gingras, M.L., Crane, N.L., Short, S.D., 1994 Early life history studies of nearshore rockfishes and lingcod along the Centra California coast from 1987 through 1992. Administrative Report, CDFG Marine Resources Division.

Wing, S.R., Botsford, L.W., Largier, J.L., Morgan, L.E., 1995a. Spatial structure of relaxation events and crab settlement in the northern California upwelling system. Marine Ecology Progress Series 128, 199-211.

Wing, S.R., Largier, J.L., Botsford, L.W., Quinn, J.F., 1995b. Settlement and transport of benthic invertebrates in an intermittent upwelling region. Limnology and Oceanography 40, 316-329.

Yoklavich, M.M., Loeb, V.J., Nishimoto, M., Daly, B., 1996. Nearshore assemblages of larval rockfishes and their physical environment off central California during an extended El Nino event, 1991-1993. Fishery Bulletin 94, 766-782. 